\title{
All by Themselves? Legislative Regions and the Use of Unmediated Access to the European Level
}

Anna-Lena Högenauer, Maastricht University

Final version published in the European Political Science Review

\begin{abstract}
Since the 1980s, the level of activism of regions in EU policy-making has greatly increased, leading to the emergence of claims that regional governments can and do bypass national government in European negotiations. However, two decades after the emergence of the concept, the debate about the ability of regions to engage successfully in this process of continuous negotiation and to represent their interests on the European stage is ongoing. Due to the scarcity of research looking at regional interest representation in concrete cases of policy-making, it has been difficult to establish to what extent and under which circumstances regions do rely on unmediated channels of interest representation on the European level. This article examines these questions through the activities of seven legislative regions during two negotiations of European Directives, as legislative regions have a wider choice of channels of interest representation. Overall, extensive use of unmediated access in regulatory policy-making is rare and can best be explained with reference to domestic conflict and the level of influence of a region in domestic European policy-making. Differences in the size of a region also influence the ability of a region to represent its interests in the coordination of the national position and at the European level.
\end{abstract}




\section{Introduction}

Since the 1980s, the level of activism of regions in EU policy-making has greatly increased. This is reflected in the exponential rise in the number of regional offices in Brussels, calls for formal regional representation through institutions such as the Committee of the Regions and - especially in the 1990s - demands for a 'Europe of the Regions'. In the early 1990s, these developments inspired Gary Marks' concept of multilevel governance (MLG) in EU policy-making as a challenge to the state-centrism of existing integration theories. Marks defined multi-level governance as "a system of continuous negotiation among nested governments at several territorial tiers" (Marks 1993: 392). However, two decades after the emergence of the concept, the debate about the ability of regions to engage successfully in this process of continuous negotiation and to represent their interests on the European stage is ongoing.

Despite the undeniable increase in regional activity on the European level, some authors argue that domestic channels of interest representation are still more effective than European ones (Jeffery 2000). However, due to the scarcity of research looking at regional interest representation in concrete cases of policy-making, it has been difficult to establish to what extent regions do rely on European channels and even more difficult to analyze the influence they could exercise through them.

Legislative regions are a particularly interesting case. As European integration has led to a partial transfer of their legislative competences to the European level, these regions 
have a strong incentive to influence European legislation in order to balance this loss. In addition, in the light of the negotiations of the Constitutional Treaty and the Treaty of Lisbon, it seems that strong legislative regions have started to concentrate on preserving national competences and on opposing a deepening of European integration as they struggle to gain a satisfactory level of influence over EU policy-making (Jeffery 2007). Nevertheless, with greater resources and political legitimacy than regions in other member states, they can be expected to have the greatest impact on the European level. At the same time, the constitutionally guaranteed possibilities of influencing the position of their national governments provide these regions with several channels of interest representation and a certain choice as to where and how they wish to invest their resources.

At the heart of this article thus stand two questions: To what extent do strong legislative regions choose to represent their interests through 'bypassing' on the European level? And what factors influence this choice? In order to address these questions, the first section will review the literature MLG and on relevant factors for the choice of strategy with a view towards developing a set of hypotheses. The second section will discuss the methodology and case selection. In order to assess the extent of the use of unmediated channels, the article analyses the strategies of regions in two concrete policy cases, the Bathing Water Directive and the Flood Risk Management Directive. It will focus on seven regions from four federal or quasi-federal member states (Scotland, Flanders, Wallonia, Carinthia, Vorarlberg, Mecklenburg-West Pomerania and Bavaria), thus having 14 cases ( 7 regions $\mathrm{x} 2$ policies) that allow for the analysis of a variety of factors. 
The third section will analyze the accuracy of various explanatory factors and the role of unmediated access in the strategies of legislative regions and argue, in particular, that domestic conflict and the level of influence of a region in domestic European policymaking play an important role in explaining the occurrence of unmediated strategies of interest representation.

\section{Multi-level Policy-Making and Regional Interest Representation in the}

\section{EU}

The multi-level governance approach claims that "subnational interests mobilize beyond the reach of national governments directly in the European arena" (Hooghe and Marks 2001: 12) and thus gives rise to two rudimentary hypotheses. Firstly, there will be direct interaction between subnational and the supranational actors unmediated by central governments. Secondly, this interaction will to some extent undermine the authority of central governments (cf. Sloat 2002: 37-8).

Over time, the MLG literature developed a more precise set of hypotheses with regard to regional mobilization and influence in EU policy-making. This was an important step; the EU's regions vary on a wide variety of factors and - as a consequence - do not all act in the same way (Hooghe and Marks 2001: 82, 92; Jeffery 2000).

The impact of the national context on regional mobilization and influence in the EU policy-making process is widely recognized, most notably through the use of "regional domestic competences" as an independent variable (e.g. Marks, Haesly and Mbaye 2002; 
Marks et al. 1996; Jeffery 1997; Jeffery 2000; Nielsen and Salk 1998; Moore 2006). However, while early studies argue that greater constitutional strength has a positive impact on the lobbying activities of a region (Marks et al. 1996; Nielsen and Salk 1998; Marks, Haesly and Mbaye 2002), Tatham (2010) suggests that regions with a greater number of competences are less likely to engage in conflictual strategies in Brussels and more likely to cooperate with their central governments.

Similarly, Marks et al. (1996: 181) argue that the level of resources available to regions is reflected in the size of the Brussels office and Nielsen and Salk (1998) find that economically strong regions were more likely to have a Brussels presence. They also find that the size of the region is positively associated with the existence of a Brussels office. By contrast, Tatham (2010) argues that neither the size of a region nor the economic strength of a region influence whether a region cooperates with its central government in Brussels.

Both Tatham (2010) and Bauer (2006) identify party politics as an explanatory factor for inter-regional differences in preferences or the style of interest representation.

Finally, Jeffery adds formal structures of intergovernmental relations, administrative adaptation, leadership and coalition-building and legitimacy and social capital as having an impact on the capacity of a region to influence European policy-making (Jeffery 2000: 14-7).

While some of these factors have been developed as a means to explain differences in influence or preferences, some of them can also be seen as relevant for the level and type 
of regional mobilization. However, with the exception of the impact of the constitutional strength of regions on their mobilization in EU policy-making and - to a lesser degree the impact of party politics and a region's socio-economic situation, these factors are still largely hypotheses that have experienced limited empirical testing. This makes MLG vulnerable to criticism as a model of European policy-making and limits the explanatory potential that the literature can develop. The challenge for the MLG literature is thus to address the question why, when, how and which regional governments try to establish unmediated access to the European level.

For the purpose of this article, the definition of "unmediated access" is that a region becomes active on the European level in a way that does not require prior coordination with the central government. This includes asking MEPs to defend a certain stance, taking part in Commission consultations, attending the Committee of the Regions, the use of regional offices to approach Commission officials or organize lobbying events and participation in conferences and workshops that are designed to inform and influence European decision-making. Participation in the Council of Ministers, the COREPER, Council working groups, Commission committees or stakeholder meetings does not qualify as unmediated access, as it requires prior negotiations with the central government (often permission of the central government) and - most notably - the prior agreement of a common national position.

The explanatory framework for the strategies of interest representation of legislative regions in European policy-making will focus on regional governments as rational 
collective actors, as many MLG approaches are seen to be implicitly rational institutionalist (especially by Marks and Hooghe).

The first question is why regions would mobilize at all, irrespective of the precise strategy. The assumption is that regions are essentially utilitarian and mobilize in response to self-interest. ${ }^{1}$ In everyday policy-making, this essentially means that they are affected by the policy problem (salience). In addition, the extent of a region's competences in a given policy area will affect its propensity to mobilize in EU policymaking. Regions that have implementation competences either have to carry the cost of implementation and policy adaptation or - in the case of distributive policies - receive the benefits. In addition, regions with policy-making competences in the area will find their margin of manoeuvre restricted by new European rules (Knodt 2000: 238; Bußjäger and Djanani 2009: 58).

The second step is to identify the factors that would entice a regional government to engage in a multi-level rather than a two-level strategy of interest representation. The assumption is that it is generally less costly and more effective for legislative regions to work through their member states (cf. Tatham 2012). While the process of formulating the national position varies between member states, legislative regions generally have at least the right to be informed and consulted. In addition, regions usually gain some form of inclusion into the national delegation either collectively or individually at least at the drafting stage of the policy and at the implementation stage. Finally, provided that the

\footnotetext{
${ }^{1}$ This study relies on a subjective definition of a region's preferences concerning a given policy (derived through interviews and documents).
} 
region is pleased with the national position, it can effectively "free-ride" and leave the task of defending that position to the central government (which most of the time has the core competence in representing the member state abroad).

By contrast, regions have only one automatic access point to the European level, the Committee of the Regions. As action through this channel requires the support of hundreds of regions and local authorities just to reach a consultative position, this is not a very effective channel. All other forms of unmediated access are informal and require prior investment into the establishment of access, the formalization and translation of the regional position and, due to the large number of lobbyists in Brussels, have to be heavy on expertise and/or command strong political support domestically. Therefore, the assumption is that regional governments will automatically participate in domestic European policy-making, but require specific incentives to develop a multi-level strategy.

Three factors could potentially influence the choices of legislative regions by diminishing the effectiveness of the domestic approach (cf. Jeffery 2003). Thus, strong conflict over the policy issue between regions or between the central government and regions could either prevent a strong national position from emerging or (depending on the precise processes) result in a region being outvoted. Secondly, competition between different parties in power at the national and the regional level or the existence of regionalist governments could jeopardize the willingness to compromise at home and provide an incentive to regional governments to openly pursue conflicting goals at the European level (cf. Knodt 2000: 241). Thirdly, the degree to which domestic processes confer power on regions may influence their willingness to rely exclusively on these processes. 
What could influence domestic regional influence is the number of actors involved at that stage, the formal or informal nature of regional involvement and whether formal involvement takes the form of co-decision or consultation. It depends thus heavily on domestic institutions. The hypothesis is that regions that have little influence domestically will be more inclined to focus their resources on European channels of interest representation. Alternatively, one might expect the regions of cooperative federal system to be less inclined to use unmediated access than the regions of dual systems (cf. Börzel 1999).

A third consideration is that there are enabling and constraining factors that influence whether a region can adopt a multi-level strategy and to what extent it can become active (cf. Jeffery 2000; Bauer 2006; Knodt 2000). They can be expected to have an impact across the board. As a European level strategy requires a higher investment in terms of money and personnel, larger regions and economically stronger regions can be expected to find it easier to establish unmediated access to the European level than small and economically weaker regions as their capacity to plan and execute such a strategy is greater. It is also in this respect that the choice of policy area under investigation may be relevant, as economically weaker regions can be expected to focus their resources on financially enabling distributive policies.

On the whole, there are thus seven factors in three different categories that can be expected to influence whether a region mobilises, whether it does so through domestic channels only or also through European channels and how active it can become. The cases were selected so that they fulfill the first two factors, to ensure that regions have in 
principle a reason to mobilize (domestically or at the European level). The impact of party constellations could not be analysed due to the fact that nearly all regions had a partial overlap of governing parties in the region and at the centre for most of the time and that the party systems were too diverse to allow for cross-country comparison. However, the interviews revealed that the civil servants did not feel that party politics mattered, with the exception of Scotland under the SNP government (e.g. Interviews 1, 7, 8). This may be due to the fact that the two case study Directives, like many (but by no means all) European regulatory policies, did not appeal to specific ideologies. The factors under investigation were thus the remaining four factors. 
- Factors Influencing the Motivation for Mobilization

A region is more likely to mobilize if...

- The policy problem is salient for a region.

- The region has competences in that policy area.

- Factors Influencing the Choice of Strategy

A region is more likely to seek unmediated access to the European level if...

- there is domestic conflict.

- there is party incongruence between the regional and the central government or ethno-regional parties are in government.

- The influence of a region in domestic European policy-making is low. OR: Regions from dual systems are more likely to seek unmediated access to the European level than regions from cooperative systems.

\section{- Enabling or Constraining Factors}

A region's capacity to develop an extensive (and multi-level) strategy

depends on...

- its economic strength.

- its size (in population).

\section{Case Selection and Methodology}

\section{The Case Selection}

So far, much of the research that argues that regions interact autonomously with European institutions (without the mediation of the central state) has an empirical focus on distributive policies, most notably regional and cohesion policy (cf. Sloat 2002). However, structural policy is one of the rare distributive policies of the European Union. Firstly, distributive policies differ from regulatory policies in that they have an inherent potential for an enabling impact on regions - they provide resources (Moravcsik 1994: 
53). Secondly, regional policy probably makes some form of involvement of regions as the implementing level nearly inevitable, so that the policy area represents an ideal case for MLG (Sloat 2002: 50). Thirdly, the policy is based explicitly on a partnership principle and thus requires the mobilisation and inclusion of sub-state actors - which is not the case for other EU policies (cf. Sturm 2009: 17).

Instead of this rare "ideal" cases for MLG, the aim is to widen the empirical basis of MLG and to analyse to what extent regions seek unmediated access to European institutions in a regulatory rather than distributive policy area, as the bulk of EU policymaking is regulatory (Hix and Götz 2000: 4-5; David Levi-Faur 2007: 102). The aim is to find a "good" case for MLG that is relatively representative of European policy-making, affects the regions under investigation and that provides some incentives to mobilise. The policy area that was selected is environmental policy, with a focus on the Bathing Water and Flood Risk Management Directives.

In addition, the article focuses on six regions from three federal states, Germany (Bavaria and Mecklenburg-West Pomerania), Austria (Carinthia and Vorarlberg) and Belgium (Flanders and Wallonia), and on Scotland as part of a quasi-federal devolution arrangement. All of these regions are legislative regions, are affected by the policy problems (salience) and have at least implementing powers in the policy area. The Belgian and German regions and Scotland have also legislative powers (the Austrian regions having few legislative powers). In addition, as all of these regions have some input into the formulation of their respective member state positions (ranging from consultation to co-decision), they also have a choice between state-centric and EU- 
focused strategies of interest representation or, of course, a combination of both. The decision to include the UK into a group of otherwise federal states was not only based on the fact that - domestically - Scotland can easily compare with the Belgian, German and Austrian regions in terms of its level of competences in everyday policy-making. It also stems from desire to increase the number of cases across which the hypotheses about the impact of domestic processes on the strategies of regions can be tested. The fact that with the UK the project spans two cooperative federal states and two dual political systems (the UK and Belgium) creates both variety and balance in the types of domestic processes under investigation. It also allows the testing of hypotheses about the impact of cooperative or dual systems that are already present in the Europeanisation literature (e.g. Börzel 1999).

There are thus 14 cases, which allows for a study of factors through an overall comparison, but also through smaller subsets of (most similar) cases. This facilitates the analysis of several factors, including factors for inter-state variation (intergovernmental relations), intra-state variation (economic strength, size) and, more generally, of conflict with the central government.

The main source of data are qualitative interviews with regional, national and European officials, which have been triangulated with documents about regional activities such as press releases and reports. Due to the limited space and the number of cases, the data will be presented in a condensed format for the sake of comparison, especially where the reconstruction of events and activities is concerned. Reference to specific interviews will 
only be made in the case of opinions on certain aspects. A complete overview of interviews used to compile the cases is therefore provided in the bibliography.

\section{The Dependent Variable - Unmediated Access}

The objective of the project is to assess to what extent the case study regions established access to European actors that was unmediated by the central state, which channels they used for this purpose and what explains variation in the degree to which such access was established.

Thus, the first question is simply whether the region established unmediated access to the European level. There are a vast number of ways in which a region could establish such access, but the most common of them are through contact with the region's (or leading) MEPs, contact with the Commission, the organization of activities through the regional office in Brussels, participation in activities on the EU level, direct contact with other member states or regions on the issue in question or active participation in the discussions in the Committee of Regions. Participation in Council meetings or Commission working group meetings will not be counted as unmediated access, as this is normally done as part of a national delegation and thus subject to prior negotiation with the central government.

The second step introduces a distinction between the regions that have been active at the European level based on frequency and level of the engagement: Has a region used just one of the channels above or several? Has it been active over a period of time? Did the region present its interests under a technical "problem-solving" approach where it tried to 
persuade other actors of its position, or did it use an overtly political approach, where politicians rather than civil servants were at the front line?

\section{Independent Variables}

\section{Conflict}

The presence or absence of domestic conflict is expected to be one of the most powerful explanatory factors for interregional variation in strategies of interest representation that could potentially cancel out the effects of other factors, most notably the impact of domestic processes: When all relevant actors within a member state broadly agree on a policy line, it may not matter much whether a region has formal co-decision rights or just consultation rights. Its position will inevitably be reflected in the member state's position. The intergovernmental relations variable (see below) may then not matter much. Regions might still mobilize on the European level in the absence of domestic conflict to support their member state, but it is less likely.

Unfortunately, conflict is one of the more elusive variables. The negotiations between the central government and the regions (or between regions) often take place in informal meeting or through emails and phone calls and that there are usually no official documents that reflect this process (Tatham 2008: 495). As a result, the extent of conflict had to be determined through interviews with officials from the relevant member states and regions. 
In terms of operationalization, cases will be divided into two categories, "conflict" and "no conflict" on the basis of the subjective perception of interviewees. "No conflict" does not mean that there are no differences between the positions of regional and central governments whatsoever, but that interviewees do not perceive these differences as problematic. Conversely, "conflict" means that interviewees felt that internal disagreements proved to be a "real" challenge for the internal coordination process. The reason why a black-and-white typology rather than a greyscale was chosen is that the narratives are expected to be too subjective to provide a basis for a distinction of 'more' or 'less' conflict across countries.

\section{Formal Domestic Processes}

One factor that has been largely ignored in the literature is the impact of domestic intergovernmental relations on regional mobilisation. "Intergovernmental relations" can be broken down into two dimensions, both of which will be taken into account in the analysis. The first dimension focuses on the level of influence that a region can exert over domestic European policy-making. It is thus primarily about formal procedures for involving regions in the formulation of a member state's position, but it also has to take into account the extent to which informal practices may shift the balance of power. The hypothesis is that regions with a high level of influence over their member state's position will feel less of a need to seek unmediated access to the European level than regions with a relatively low level of influence. 
An alternative hypothesis is derived from Börzel's German-Spanish comparison (Börzel 1999). Thus, an alternative hypothesis is that regions from dual systems (Belgium, Scotland-UK) are more likely to become active at the European level than regions from more cooperative systems (Germany, Austria). This can be based either on the assumption that regions from cooperative systems have been socialized into cooperation and consensual decision-making or on the assumption that the already existing structures for cooperation make a collective approach easier to realize for cooperative federal states. Conversely, regions form dual systems may be less used to compromises and more assertive in "their" policy areas and may also have less developed contacts to other actors in their member state. It is important to note, though, that the difference between cooperative and dual systems may not be as clear cut. On the one hand, several authors have argued that the German Länder have become more competitive over time, especially after reunification (Jeffery 2005; Knodt 2000). On the other hand, Belgian intergovernmental relations are sometimes being described as becoming more cooperative as a result of the pressures of European decision-making (Beyers and Bursens 2006).

\section{Economic Strength and Size of the Population}

Economic strength and size in terms of population are used as proxy variables to determine the capacity of a region to pursue an unmediated strategy of interest representation. The assumption is that economically strong regions have a greater income and can afford to invest more resources than economically weak regions. The GDP/head 
of a region was used as a measure for economic strength, as this is the basis for the assessment of regions for a number of EU policies (especially regional and cohesion policies) (cf. European Commission, Communication 2007). The points of reference are two years that correspond to the early phases of the negotiations for the two policies respectively - 2002 and 2006.

The case study regions were selected in such a way that for each of the countries there is one region with a relatively high GDP/head and one with a relatively low GDP/head. Scotland occupies the middle ground for the UK. Thus, this hypothesis focuses on interregional comparison (economically strong regions compared to economically weak regions). In order to neutralize the impact of different domestic processes, the comparison will take place within the pairs of regions from the same member state. For 'population size', an attempt was made to also select all regions in such a way that there would be a clear difference in the size of the two regions from each member state. Of course, this also means that the differences in size and in economic performance should not overlap perfectly. If the three economically strong regions are also the three larger regions, any difference in their strategy could be attributed to either of these factors. Thus, while there is an overlap between size and economic performance for the German and Belgian regions, the Austrian regions were chosen in such a way that the more populous region is also the economically weaker region.

\section{The Use of Unmediated Access in Environmental Policy-Making}


The first observation is that the use of unmediated channels of interest representation was generally limited. Table 1 presents a concise overview, which classifies the extent of unmediated access as 'none', 'limited' (i.e. the use of one channel, very sporadic), 'extensive' (i.e. the use of multiple channels). Table 1 shows that in half of the cases, the regions did not establish unmediated access at the European level at all. Of the remaining seven cases, five involved a limited amount of unmediated access - usually contact with MEPs - and only two included the use of several channels or a variety of actions. It should again be noted that all of the regions were affected by the policy problem and had competences in the policy area. In addition, all of the regions were actively involved in the domestic coordination of the policy (cf. Högenauer 2011).

\section{Table 1 here}

\section{Domestic Conflict as a Motivational Factor}

Table 2 shows that the relevance of conflict as an explanatory factor was confirmed. In all those cases where regional or central government positions on the Directives diverged noticeably (esp. Scotland on Bathing Water and Bavaria, Flanders, Wallonia and, to a slightly lesser degree, Mecklenburg-West Pomerania on Floods), there was at least some recourse to channels that provide unmediated access. In seven out of nine cases where regional officials felt that the position of the central government and the other regions was in line with their region's interests from the outset, there was exclusive reliance on domestic mechanisms. The two remaining cases were Flanders and Wallonia on bathing water. The Bathing Water Directive had conflict potential for Belgium as Flanders could 
have afforded to push for stricter standards than Wallonia, but a willingness to defend more moderate standards and address the differences at the transposition stage meant that the conflict never really materialized. Both regions nevertheless contacted select MEPs during the negotiations. This may be due to the importance of the Directive for the two regions. For Flanders, the coastal bathing waters contribute to its tourist industry. Wallonia, by contrast, had previously lost an infringement procedure under the old Directive and may have been concerned about the additional burden of the new Directive. In addition, it is likely that the Flemish activity was part of and a result of its official role in the Belgian national delegation. As Flanders had the pilot on this dossier, it had the lead negotiating position on the Belgian team during the drafting stage of the Directive.

\section{Table 2 here}

However, while conflict thus provides a strong explanatory factor for the absence or presence of a European level strategy of unmediated access, it cannot on its own explain the extent to which regions seek unmediated access or the precise manner in which they state their points. In the case of Germany and the Flood Risk Management Directive, the more extensive Bavarian strategy compared to Mecklenburg-West Pomerania could potentially reflect the more extreme opposition to the Directive. Then again, there was strong conflict on certain points in Belgium especially for the Flood Risk Management Directive, and yet only limited unmediated access was established. In addition, there was a qualitative difference between extensive Scottish lobbying on bathing water and the extensive Bavarian strategy on flood risk management. In the Bavarian case, three 
ministers lent their political weight to the strategy, while in the Scottish case, the activity remained technical and low-key and de-emphasized national conflict. Thus, while conflict appears to be an important explanatory factor for European level action, it is not sufficient to explain the full degree to which a region becomes active. Instead, as will be discussed below, it is worth considering other factors, such as domestic structures as additional explanatory factors, especially for the degree to which a region has recourse to unmediated access and the manner in which it presents its arguments.

\section{Intergovernmental Relations: Domestic Incentives as Disincentives for European Action?}

The analysis of the impact of intergovernmental relations was broken down into two rivaling hypotheses. The first hypothesis suggested that regions from dual systems (UK, Belgium) would be more active than regions from cooperative systems (Germany, Austria), either due to socialization effects or pre-existing structures facilitating domestic cooperation in cooperative systems.

The emergence of "conflict" as an important explanatory factor means that it has to be taken into account in the analysis of the impact of intergovernmental relations. In three out of four case study member states, negotiations on one of the two Directives gave rise to internal disagreements. As a result, the strategies of the German and Belgian regions on flood risk management and of Scotland on bathing water were all situated in a context of domestic conflict and are thus broadly comparable. There was no domestic conflict on either Directive in the case of Austria. Consequently, the Austrian cases are en par with the German and Belgian cases on bathing water and Scotland on flood risk management. 
The cross-country analysis of the impact of domestic channels of interest representation on European level strategies is however most fruitful in the context of conflict. In those cases where domestic conflict was absent, the regions generally did not perceive a need for extensive European activities.

Conflict, by contrast, produced European level strategies and variation both in terms of quantity (the number of actions) as well as quality (the nature of actions). The question is which of the hypotheses has greater explanatory power for the differences between the regions of the three member states where such conflict occurred. Table 3 summarizes the expected outcomes under each hypothesis as well as the actual findings.

If the hypothesis that regions from dual systems were more inclined to seek unmediated access held true, we would expect to see more extensive or assertive European level strategies from Scotland and the Belgian regions than from the German Länder and - if there had been a comparable case - the Austrian Länder. This is not reflected in the data. Bavaria developed by far the most extensive and assertive strategy of unmediated interest representation of all case study regions during the negotiations of the Flood Risk Management Directive. Its activities were sustained and varied, ranging from argumentation on the technical level through participation in the Commission consultation, the distribution of a cost-estimate of implementation and the organization of a Brussels event to political protest through ministers at conferences and hearings of the European Parliament. Secondly, the politicizing of the question is unparalleled, with three different ministers including the Bavarian prime minister publicly supporting Bavaria's strategy to oppose the Directive at different stages and personally visiting Barroso. While 
the extent of these activities was unique even among the German Länder and extensive by Bavarian standards, it was not the only German Land with direct ministerial involvement. The Minister of the Environment of Lower Saxony met Commissioner for the Environment Stavros Dimas, for example (Ministerium für Umweltschutz, Niedersachsen, 2006). By contrast, Scotland's strategy on bathing water was also quite extensive, but stayed firmly on the technical level and de-emphasized the UK's internal disagreements. The key officials invested time in the negotiations, meeting Commission officials, attending several workshops and briefing key Scottish MEPs regularly also with a view for them to pass the Scottish position on to the leaders of political groups in the European Parliament. Yet, while interviewees from other member states and the Commission were aware of the Scottish activism and of different Scottish and UK approaches, they did not pick up on any UK-internal conflict (cf. Interviews 27, 29; Oral communication 4). Flanders and Wallonia, by contrast, as well as Mecklenburg-West Pomerania, just briefed MEPs. The Belgian regions are thus at the lower end of the spectrum.

\section{Table 3 here}

The second hypothesis accounts better for the extent of unmediated access. Under this hypothesis, we would expect regions that are in a weak position in domestic European policy-making to be more prone to seek unmediated access to the European level, as they are less able to ensure that their point of view is included in the national position of the member state. Thus, we would expect Scotland to seek unmediated access to the 
European level, as it has only consultation rights with in the UK system and is firmly placed under the UK lead when part of the national delegation (cf. Cairney 2006; Swenden 2009). As Table 1 showed, this was the case.

In the German case, when the core competences of the Länder are affected, their position has to be taken into account extensively by the German government in drafting the national position. As a result, the extent to which the Länder are constrained domestically depends on the outcome of this contest of wills (cf. Kovziridze 2002; Müller-Graff 2005). But in addition, the larger number of regions (16) limits the impact that an individual region can have. In the case of flood risk management, the central government took on board the substantive demands, but not the demand that the Directive be vetoed. Thus, while acknowledging that the central government negotiated well on specific details, those Länder that attached great importance to the principle that the Directive breached subsidiarity (e.g. Bavaria) felt frustrated and felt the need to devise their own activities. There was thus some reason for mobilization on the European level. Like Scotland, Bavaria did indeed make extensive use of unmediated channels of interest representation.

The Belgian regions have veto-powers over the national position in areas that fall under their exclusive competences (i.e. both bathing water and flood risk management), and they de facto agree the Belgian position among themselves (cf. Lambertz and Förster 2009; Beyers and Bursens 2006). The coordination process is orchestrated by a regional official and each of the regions can veto the national position if it deems that its interests are not sufficiently reflected. For the Bathing Water and Flood Risk Management Directives, the national position mostly required negotiations between only two regions, 
as Brussels was less interested. The second hypothesis would thus expect little unmediated activity at the European level, as domestic influence is so extensive. Again, this was confirmed by the data.

In addition, the interview data shows indeed that, due to the extensive co-decision rights of the regions in the domestic process of coordination, the Belgian regions do not normally feel the need to go beyond that mechanism (Interviews 21, 23, 24). The fact that only three - or in the case of the Flood Risk Management and Bathing Water Directives de facto only two - actors co-determine the Belgian position, makes it difficult to then publicly challenge that position. Nevertheless, it is common and acceptable to consult MEPs, as this does not require a very public challenge to the Belgian position (Ibid.).

The data thus confirms the second hypothesis. This is also in line with the literature on the German and Belgian regions in the European Union. Thus, the German Länder are widely acknowledged to be very active actors in the European Union and to pursue their own unmediated activities at the European level. The eagerness of the German Länder to establish offices in Brussels in the 1980s - before many other regions - is often emphasized, as well as their engagement in the European constitutional debate (Marks et al. 1996; Pahl 2003; Georgen 2004: 136). Conversely, the literature on the Belgian regions tends to emphasize their strong position within the Belgian federal state and how they were given a corresponding role in Belgian European domestic policy-making over time as part of the principle in foro interno in foro externo (e.g. Bursens and Geeraerts 2006:173; Beyers and Bursens 2006). There is also a feeling that this part of policy-making 
has so far remained relatively unscathed by Belgium's internal conflicts (Lambertz and Förster 2009: 24).

However, one also has to take into account attitudes to political assertiveness. As discussed above, Bavaria engaged in its unmediated strategy openly and at a political level whereas Scotland kept its strategy focused on substantive arguments and low key. This phenomenon is also documented in the literature. Thus, Jeffery has previously described Bavaria's strategy in the European Union as focused on visibility and symbolism (Jeffery 1998; Hübler 2003). The literature on Scotland has, by contrast, highlighted the extent to which Scotland (and the UK) avoid exposing internal conflict at the European level and acknowledges Scotland's low key, detail-focused approach (Cairney 2006: 439). This may at least in part be linked to the fact that the participation rights of the German Länder are constitutionally guaranteed, whereas the UK government can to some extent withdraw access to negotiations from non-compliant devolved governments (Rowe 2009; Moore 2006).

\section{Inter-Regional Differences: Wealth and Size}

Two factors for cross-regional variation that can be analyzed as part of the comparison are the impact of the economic performance of a region and its size in terms of population (cf. Marks et al. 1996; Nielsen and Salk 1998; Tatham 2010; Bauer 2006). Both of these factors could facilitate a proactive approach. GDP per head was chosen as an indicator for wealth, as it measures the wealth of a region per capita (and thus does not overlap with size). The size in terms of population was chosen because it was assumed 
that the costs of a specialised administration for European affairs (e.g. a Brussels office) would be easier to bear for a more populous region than a very small region.

As both conflict and intergovernmental relations matter, the impact of the wealth and size of a region can best be assessed by holding these two factors constant. This can be achieved through a sequence of comparisons within a country, i.e. by looking at the Belgian, German and Austrian regions as pairs, with each pair containing, for example, a richer and a poorer region. In this effort, the analysis will go beyond the fourteen case studies and also use the interviewees' impressions their region's strategy and the strategies of other regions from their member state.

Table 4 summarises the main findings. Within the three pairs of regions, Bavaria, Flanders and Carinthia are generally deemed to be more active in European policymaking. In addition, the interviews showed that Scotland is more active than Wales or Northern Ireland (Interviews 33, 34).

\section{Table 4 here}

In the German case, Bavaria was considerably more active on the European level on flood risk management than Mecklenburg-West Pomerania. Whereas Bavaria developed an elaborate strategy involving three ministers, the organisation of an event in Brussels and the briefing of MEPs, Mecklenburg just briefed its MEPs once. In addition, Bavaria was very vocal in the domestic coordination process and even expressed interest to provide the representative of the Bundesrat. On bathing water, neither of the regions 
became active at the European level, but Mecklenburg was seen to be more active within Germany (Interviews 7, 9). More generally though, the German interviewees felt that Bavaria tends to be one of the most active German Länder both internally and at the European level. Its less active stance during the coordination of the German position on bathing water was thus regarded as atypical and linked to restructuring and changes of personnel that may have led to an adaptation period (ibid.). Bavaria's general activism on European matters has also translated into investments into its Brussels office. Whereas Mecklenburg has seven policy officers in Brussels, the Bavarian representation had at the time in total about 30 members of staff (including support staff) and was expanding (Bavarian State Chancellery 2008: 7).

The differences in activism coincide with clear differences in population size and economic performance. Bavaria with its 12.5 million inhabitants dwarfs Mecklenburg with its 1.7 million inhabitants. While Mecklenburg-West Pomerania is still bigger than some of the EU's member states, the interviewees were aware that the region is one of the smaller German Länder, feared that it might be a "light weight" in Brussels, and felt that this influenced negatively its ability to devote staff to interest representation on specific policies and gave it less clout in negotiations with the Commission (Interview 6). In addition, in terms of GDP per head, Mecklenburg is one of the economically weakest German Länder while Bavaria is one of the leaders. The fact that Bavaria tends to be more active than Mecklenburg is thus in line with the hypotheses about size and economic performance. 
In the case of Belgium, both regions developed similar strategies of unmediated access to the European level. Internally, however, it is estimated that, due to greater administrative resources, Flanders provides pilots ${ }^{2}$ more frequently than Wallonia (Interview 21, 24). Since the early 2000s, Flanders has put in place a number of measures designed to give it a competitive edge in domestic European policy-making more generally. Thus, in order to give the Flemish position maximum effectiveness, the region has introduced the role of "Vlaamse trekker". It is the task of the trekker to make sure that there is a well prepared and coordinated Flemish position even when Flanders is not responsible for coordinating the Belgian position. In addition, Flanders has improved the access of officials to ministerial advisors to ensure that the Flemish position has political support in the case of conflict with other Belgian actors (Interview 20, 24). Thus, in line with the Belgian focus on domestic coordination, the investments of the Belgian regions are into the administrative effectiveness at home. As in the German case, the difference in activism coincides with differences both in population size and economic strength (Flanders being larger and economically stronger).

The same pattern is repeated in the case of the UK. Scotland is economically somewhat stronger than Northern Ireland and Wales and considerably larger in terms of population. As Wales and Northern Ireland were not part of the case studies, their European strategies on the two Directives are unknown. However, the size of the regional offices can be used as an indicator for their investment into European level strategies. Thus, Moore reveals that in 2004 the total number of staff employed by the SGEUO was 12,

\footnotetext{
${ }^{2}$ A pilot is the official coordinating the national position.
} 
nearly twice as many as Wales' seven and more than twice as many as Northern Ireland's five members of staff (Moore 2004: 146). Within the UK, the Scottish government was more active than the other devolved executives in the coordination of the UK positions on bathing water and floods. It also participated more actively and numerously in the national delegations to Commission and Council meetings (Högenauer 2011). Again, interviewees felt that this was typical for the UK and the literature confirms that Scotland is generally more active in domestic European policy-making and better staffed than its devolved counterparts. Both the literature and interviewees attribute this directly to Scotland's greater size and - compared to Wales - to its greater competences (Trench 2008: 222; Swenden 2009: 106; Interviews 31, 33, 34).

As greater size and greater economic strength have so far coincided, the data is inconclusive as to whether size or economic strength or both matter. The two Austrian regions were interesting in that regard. Carinthia has the larger population but Vorarlberg has a higher GDP per head. While neither of the regions developed a strategy of unmediated access to the European level, Carinthia was more active in the domestic coordination (Högenauer 2011; Interview 11). More generally, the fact that Carinthia has an office in Brussels with two policy officers whereas Vorarlberg is the only Austrian region not to have an office suggests that Carinthia is also more likely to become active on the European level in general. In the Austrian case, size thus appears to be of greater importance than economic performance.

\section{Conclusion}


The analysis of the strategies of seven regions in the negotiation of two environmental Directives suggests that the extensive use of unmediated access is relatively rare, even for legislative regions. In those cases where unmediated access took place, it was often limited to a briefing of MEPs - a low cost one-off measure. The core element in the strategies of legislative regions is thus participation in domestic European policy-making. However, this does not necessarily mean that central governments can assume a gatekeeper function, as the examples of extensive use of unmediated channels suggest that regions can and do bypass the central governments in select cases where they are dissatisfied with the national position and find the policy problem sufficiently salient.

There is, however, considerable variation in the extent to which and ways in which unmediated access is used. Through the comparison of the fourteen cases, three key findings have emerged. Firstly, domestic conflict is an important explanatory factor for the presence or absence of unmediated activities at the European level. While some limited regional activities at the European level can occur in accordance with the strategy of the centre, conflict appears to be a key motivational factor for investments into a European strategy in the vast majority of cases. The main reason for this appears to be that conflict within a member state limits a region's ability to have its priorities included in the national position. Even if the national position is a compromise that includes aspects of the region's position, it is more likely that some of its interests are not incorporated. Conflict thus creates an incentive to supplement the national route with unmediated regional activities. 
Secondly, different processes of national coordination create different incentives to pursue a European strategy. The comparison suggests that the extent of influence over domestic European policy-making has an impact on the choice of strategy. Thus, strong legislative regions with a vast amount of influence over the formulation of the national position, like the Belgian regions, are less willing to jeopardize the smooth running of the domestic coordination process through unmediated activities at the European level, even in the face of domestic conflict. Strong legislative regions like the German Länder or Scotland, that have only a limited amount of influence over the formulation of the national position due to limited rights or the large number of actors having to agree are more inclined to develop their own strategies of interest representation at the European level, especially in the face of domestic conflict. Here, the incentive of being able to voice one's interests fully is stronger than the desire to wholly concentrate on a national position that the region can only influence to a small degree.

Finally the pattern of regional activity across the fourteen case studies suggests that the size of the region in terms of population is an important indicator for its level of activity in the domestic coordination processes and at the European level. This finding is in line with the understanding of regional officials of their work and the factors limiting their margins of manoeuvre. It has also emerged that the size of the region has a stronger impact than its economic performance. The precise impact of economic performance alone could, however, not be identified in the framework of this project.

Thus, overall, a number of factors have been identified as having an impact on regional strategies of interest representation, in line with the affinity towards rational choice 
institutionalism in the MLG literature. They can thus be used to add complexity to a concept that has sometimes been criticized for being overly descriptive and poor when it comes to generating verifiable hypotheses. On the other hand, the task of investigating the driving forces behind regional strategies is not yet complete. Further work on the impact of party politics in cases that are ideologically charged is required, as is research on regional strategies in the case of soft law compared to hard law (cf. MacPhail 2008). It is only when differences in regional strategies are openly acknowledged and explored that the concept of MLG can be further developed.

\section{Bibliography:}

Bauer M.W. (2006), "The German Länder and the European Constitutional Treaty: Heading for a Differentiated Theory of Regional Elite Preferences for European Integration", Regional and Federal Studies, Vol. 16, No. 1, pp. 21-41.

Bavarian State Chancellery (2008), Representation of the Free State of Bavaria to the European Union, Munich.

Benz A., Eberlein B. (1999), "The Europeanization of regional policies: patterns of multilevel governance”, Journal of European Public Policy, Vol. 6(2), pp. 329-48.

Beyers J., Bursens P. (2006), "The European Rescue of the Federal State: How Europeanisation Shapes the Belgian State", West European Politics, Vol. 29(5), pp. 1057-78.

Börzel T. (1999), "Towards Convergence in Europe? Institutional Adaptation to Europeanisation in Germany and Spain", Journal of Common Market Studies, Vol. 37(4), 573-596.

Bursens P., Geeraerts K. (2006), "EU Environmental Policy-Making in Belgium: Who Keeps the Gate?", Journal of European Integration, Vol. 28(2), pp. 159-179.

Bussjäger P., Djanani A. (2009), "Europapolitik und Europafähigkeit der Länder in Österreich”, in: Karl-Heinz Lambertz, Martin Grosse Hüttmann (eds.), 
Europapolitik und Europafähigkeit von Regionen, Nomos, Baden-Baden, pp. 5870.

Cairney P. (2006), "Venue Shift Following Devolution: When Reserved Meets Devolved in Scotland", Regional and Federal Studies, Vol. 16(4), pp. 429-446.

Directive 2006/7/EC of the European Parliament and of the Council of 15 February 2006 concerning the management of bathing water quality and repealing Directive 76/160/EEC, OJ L 064 , 4/03/2006, pp. 37-51.

Directive 2007/60/EC of the European Parliament and of the Council of 23 October 2007 on the assessment and management of flood risks, OJ L 288, 6/11/2007, pp. 2734.

European Commission, Communication, Growing Regions, Growing Europe: Fourth report on economic and social cohesion, Communication from the Commission, Luxemburg, Office for Official Publications of the European Communities, May 2007.

Goergen P. (2004), Le lobbying des villes et des régions auprès de l'Union européenne, D\&P Service.

Hix S.,Götz K.H. (2000), "Introduction: European integration and national political systems", West European Politics, Vol. 23(4). pp. 1-26.

Högenauer A.L. (2011), Multi-level governance revisited. Comparing the strategies of interest representation of legislative regions in EU environmental policy-making. $\mathrm{PhD}$ dissertation, University of Edinburgh.

Hooghe L., Marks G. (2001), Multi-Level Governance and European Integration, Oxford, Rowman \& Littlefield Publishers, Inc.

Hübler M. (2003), "Bayern in der Europäischen Union zu Beginn des 21. Jahrhunderts", Politische Studien, Vol. 38(8), pp. 84-95.

Jeffery C. (1997), "Regional Information Offices in Brussels and Multi-level Governance in the EU: A UK-German Comparison" in: C. Jeffery (ed.), The Regional Dimension of the European Union - Towards a Third Level in Europe?, London, Frank Cass, pp. 183-203.

Jeffery C. (1998), “Les Länder allemands et l'Europe: intérêts, stratégies et influence dans les politiques communautaires", in: E. Négrier et B. Jouve (eds.), Que gouvernent les régions d'Europe?, Paris, L'Harmattan, pp. 55-84.

Jeffery C. (2000), "Subnational Mobilization and European Integration: Does it Make any Difference?", Journal of Common Market Studies, Vol. 38(1), pp. 1-23. 
Jeffery C. (2003), "The German Länder: From Milieu-Shaping to Territorial Politics", in:

K. Dyson, K.H. Götz (eds.), Germany, Europe and the Politics of Constraint, Oxford, Oxford University Press, pp. 97-108.

Jeffery C. (2005), "Federalism: the New Territorialism”, in: S. Green, W.E. Paterson (eds.), Governance in Contemporary Germany - The Semisovereign State Revisited, Cambridge, Cambridge University Press.

Jeffery C. (2007), “A Regional Rescue of the Nation-State: Changing Regional Perspectives on Europe", EUSA Tenth Biennial International Conference, Montreal.

Knodt M. (2000), "Europäisierung à la Sinatra: Deutsche Länder im europäischen Mehrebenensystem", in: M. Knodt, B. Kohler-Koch (eds.), Deutschland zwischen Europäisierung und Selbstbehauptung, Frankfurt, Campus Verlag, pp. 237-264.

Kovziridze T. (2002), "Europeanization of Federal Institutional Relationships: Hierarchical and Interdependent Institutional Relationship Structures in Belgium, Germany and Austria”, Regional and Federal Studies, Vol. 12(3), pp. 128-155.

Lambertz K.-H., Förster S. (2009), "Die belgischen Gemeinschaften und Regionen im europäsichen Rechtsetzungsprozess", in: K.-H. Lambertz, M. Grosse Hüttmann (eds.), Europapolitik und Europafähigkeit von Regionen, Baden-Baden, Nomos, pp. 21-24.

Levi-Faur D. (2007), "Regulatory Governance”, in: P. Graziano, M. Vink (eds.), Europeanization: New Research Agendas, Basingstoke, Palgrave Macmillan, pp. 102-114.

MacPhail E. (2008), "Changing EU Governance: a New Opportunity for the Scottish Executive", Regional and Federal Studies, Vol. 18(1), pp. 19-35.

Marks G. (1993), "Structural Policy and Multilevel Governance in the EU", in: A. Cafruny, G. Rosenthal (eds.), The State of the European Community, New York, Lynne Rienner, pp. 164-92.

Marks G., Haesly R., Mbaye H.A.D. (2002), "What Do Subnational Offices Think They Are Doing in Brussels?", Regional and Federal Studies, Vol. 12(3), pp. 1-23.

Marks G., Hooghe L., Blank K. (1996), "European Integration from the 1980s: State Centric v. Multi-level Governance", Journal of Common Market Studies, Vol. 34(3), pp. 341-78.

Ministerium für Umweltschutz, Niedersachsen, Newsletter, March 2006, www.umwelt.niedersachsen.de/live/live.php?navigation_id=2149\&article_id=759 4\&_psmand=10, accessed 30/08/2010. 
Moore C. (2004), Between Diplomacy and Interest Representation: Regional Offices in the EU. A German - British Comparison. PhD thesis submitted to the University of Birmingham.

Moore C. (2006), “'Schloss Neuwahnstein'? Why the Länder Continue to Strengthen Their Representations in Brussels", German Politics, Vol. 15(2), pp. 192-205.

Moravcsik A. (1994), "Why the EC Strengthens the State: Domestic Politics and International Cooperation", Centre for European Studies Working Paper 52, Cambridge, MA, Department of Government, University of Harvard.

Müller-Graff P.C. (2005), "The German Länder: Involvement in EC/EU Law and PolicyMaking", in: S. Weatherill, U. Bernitz (eds.), The role of Regions and SubNational Actors in Europe, Oxford, Hart Publishing.

Nielsen F., Salk J. (1998), “The Ecology of Collective Action and Regional Representation in the European Union", European Sociological Review, Vol. 14(3), pp. 231-254.

Pahl M.-O. (2003), "Die Rolle der Regionen mit Gesetzgebungskompetenzen im Konventsprozess", Jahrbuch des Föderalismus, Vol. 4, pp. 462-479.

Rowe C. (2009), "On the front line: how regional representations in Brussels shape intergovernmental relations on Europe", ESRC Seminar Series - Reforming Intergovernmental Relations in a Context of Party Political Incongruence, Scotland House, Brussels, 10-11 December 2009.

Sloat A. (2002), Scotland in Europe - A Study of Multi-Level Governance, Oxford, Peter Lang.

Sturm R. (2009), “Die “Europafähigkeit der Regionen”, in: K.-H. Lambertz, M. Grosse Hüttmann (eds.), Europapolitik und Europafähigkeit von Regionen, Baden-Baden, Nomos, pp. 11-20.

Swenden W. (2009), “Schottland in Europa: Mit oder ohne Vereinigtes Königreich?”, in: K.-H. Lambertz, M. Große Hüttmann (eds.), Europapolitik und Europafähigkeit von Regionen, Baden-Baden, Nomos, pp.101-122.

Tatham M. (2008), "Going Solo: Direct Regional Representation in the European Union”, Regional and Federal Studies, Vol. 18(5), pp. 493-515.

Tatham M. (2010), "With or Without You? Revisiting Territorial State-Bypassing in EU Interest Representation”, Journal of European Public Policy, Vol. 17(1), pp. 7699. 
Tatham M. (2012), "You Do What You Have to Do? Salience and Territorial Interest Representation in EU Environmental Affairs", European Union Politics, 23/08/12; DOI: 10.1177/1465116512441505.

Trench A. (2008), "Chapter 9: The Practice of Multi-Level Government: How Intergovernmental Relations Work in Federal Systems", in: A. Trench (ed.), The State of the Nations 2008, Exeter, Imprint Academic.

\section{Full List of Interviews}

Interview 1: official (1), Bavarian Ministry of the Environment and

$4 / 03 / 2009$

Health, Munich.

Interview 2: official (2), Bavarian Ministry of the Environment and

$4 / 03 / 2009$ Health, Munich.

Interview 3: official, Bavarian Ministry of the Environment and

$4 / 03 / 2009$

Health and former member of the Bavarian Representation in Brussels, Munich.

Interview 4: official, Amt der Vorarlberger Landesregierung,

$11 / 03 / 2009$

Abteilung für Wasserwirtschaft, Bregenz.

Interview 5: official, Institut für Umwelt und Lebensmittelsicherheit

$12 / 03 / 2009$ des Landes Vorarlberg, Bregenz.

Interview 6: official, Ministry of Agriculture, Environment and

$16 / 03 / 2009$ Consumer Protection, Schwerin.

Interview 7: official, Ministry of Social Affairs of Mecklenburg-West Pomerania, Schwerin.

$18 / 03 / 2009$

Interview 8: official (1), Federal Ministry of the Environment, Bonn.

$20 / 03 / 2009$

Interview 9: official (2), Federal Ministry of the Environment, Bonn.

$20 / 03 / 2009$

Interview 10: official, Amt der Vorarlberger Landesregierung,

$26 / 03 / 2009$

Abteilung für Europaangelegenheiten und

Außenbeziehungen, telephone.

Interview 11: official, Amt der Kärntener Landesregierung, Abteilung 15, Klagenfurt.

$30 / 03 / 2009$

Interview 12: official, Amt der Kärntener Landesregierung, Abteilung 18 , Klagenfurt.

$30 / 03 / 2009$ 
Interview 13: official (1), Federal Ministry of the Environment,

$1 / 04 / 2009$ Vienna.

Interview 14: official (2), Federal Ministry of the Environment,

$1 / 04 / 2009$ Vienna.

Interview 15: official, Liaison Office of the Austrian Länder, Vienna.

$2 / 04 / 2009$

Interview 16: official, Federal Ministry of Health, Vienna.

$3 / 04 / 2009$

Interview 17: representative of the Bundesrat for flood risk

$7 / 04 / 2009$

management, telephone.

Interview 18: representative of the Bundesrat for bathing water, telephone.

Interview 19: official, Water, Air, Soils and Flooding Division of the

$6 / 05 / 2009$ Scottish Government, Edinburgh.

Interview 20: official, VMM, Brussels.

$18 / 05 / 2009$

Interview 21: official, DGARNE, Namur.

$20 / 05 / 2009$

Interview 22: former member of the Austrian Permanent

$25 / 05 / 2009$

Representation, Brussels.

Interview 23: official, Belgian Permanent Representation, Brussels.

$27 / 05 / 2009$

Interview 24: official, Flemish Delegation to the Belgian Permanent

$5 / 06 / 2009$ Representation, Brussels.

Interview 25: official, VMM, Gent.

$8 / 06 / 2009$

Interview 26: representative of the Liaison Office of the Austrian

$8 / 06 / 2009$

Länder in Brussels, Brussels.

Interview 27: European Commission official, DG Environment,

$9 / 06 / 2009$ Brussels.

Interview 28: Director of the Carinthian Office in Brussels, Brussels.

$9 / 06 / 2009$

Interview 29: European Commission official, DG Environment,

$11 / 06 / 2009$

Brussels.

Interview 30: official, Brussels office of Mecklenburg-West

$12 / 06 / 2009$ Pomerania, Brussels.

Interview 31: former official of the Water, Air, Soils and Flooding

$24 / 06 / 2009$ Division of the Scottish Government.

Interview 32: former official of the Water, Air, Soils and Flooding

$1 / 07 / 2009$ Division of the Scottish Government, Edinburgh. 
Interview 33: former official of DEFRA, telephone.

$7 / 7 / 2009$

Interview 34: official, DEFRA, telephone.

$17 / 07 / 2009$

Interview 35: official, SEPA, telephone.

$7 / 08 / 2009$

Interview 36: official, Water, Air, Soils and Flooding Division of the

$25 / 09 / 2009$ Scottish Government, Edinburgh.

\section{Oral and Written Communications ${ }^{3}$}

Oral communication 1: official, Water, Air, Soils and Flooding Division

$30 / 04 / 2009$

of the Scottish Government, telephone.

Oral communication 2: official, Walloon delegation to the Belgian

$3 / 06 / 2009$

Permanent Representation, telephone.

Oral communication 3: official, Brussels office of Mecklenburg-West

$3 / 06 / 2009$

Pomerania, telephone.

Oral communication 4: official, DG Environment, telephone.

$5 / 06 / 2009$

\section{Written Communications}

Written communication 1: official, Water, Air, Soils and Flooding

$29 / 04 / 2009$

Division of the Scottish Government.

Written communication 2: official, Flemish delegation to the Belgian

$5 / 06 / 2009$

Permanent Representation.

Written communication 3: official, SEPA.

$21 / 07 / 2009$

Written communication 4: from a Scottish MEP.

$10 / 05 / 2010$

Written communication 5: from a Scottish MEP.

$11 / 05 / 2010$

Written communication 6: official, SEPA.

$7 / 10 / 2010$

\footnotetext{
3 'Oral communication' refers to shorter conversations with officials, usually on the phone.
} 


\section{Annex 1: Tables}

Table 1: Level of Unmediated Access

\begin{tabular}{|c|c|c|c|}
\hline & & Activity & Category \\
\hline \multirow[t]{2}{*}{ Bavaria } & BW & None & None \\
\hline & Floods & $\begin{array}{l}\text { Contact MEPs, Commission Consultation, } \\
\text { Ministers get involved, Brussels event }\end{array}$ & Extensive \\
\hline \multirow[t]{2}{*}{ Meck-VP } & BW & None & None \\
\hline & Floods & Contact MEPs & Limited \\
\hline \multirow[t]{2}{*}{ Carinthia } & BW & None & None \\
\hline & Floods & None & None \\
\hline \multirow[t]{2}{*}{ Vorarlberg } & BW & None & None \\
\hline & Floods & None & None \\
\hline \multirow[t]{2}{*}{ Flanders } & BW & Contact MEPs & Limited \\
\hline & Floods & Contact MEPs & Limited \\
\hline \multirow[t]{2}{*}{ Wallonia } & BW & Contact MEPs & Limited \\
\hline & Floods & Contact MEPs & Limited \\
\hline \multirow[t]{2}{*}{ Scotland } & BW & $\begin{array}{l}\text { Contact MEPs, workshop, direct contact with } \\
\text { COM, stakeholder networks }\end{array}$ & Extensive \\
\hline & Floods & None & None \\
\hline
\end{tabular}

$B W=$ BATHING WATER DIRECTIVE

Table 2: Conflict and Unmediated Access

\begin{tabular}{|l|l|l|l|}
\hline & \multicolumn{3}{|l|}{ Unmediated Access } \\
\hline & None & Limited & Extensive \\
\hline Conflict & 0 & 3 & 2 \\
\hline No Conflict & 7 & 2 & 0 \\
\hline
\end{tabular}


Cases of conflict: Floods: Bavaria, Mecklenburg-West Pomerania, Flanders, Wallonia. Bathing water: Scotland.

Table 3: Expected Impact of Intergovernmental Relations

\begin{tabular}{|c|c|c|c|c|}
\hline & & \multicolumn{2}{|c|}{ Hypotheses: Expected Outcome } & \multirow{2}{*}{$\begin{array}{l}\text { Outcome (only in cases } \\
\text { with conflict) }\end{array}$} \\
\hline & & $\mathrm{H} 1$ & $\mathrm{H} 2$ & \\
\hline UK & Scotland & $E$ & $E$ & $\mathrm{E}$ \\
\hline \multirow[t]{2}{*}{ Belgium } & Flanders & $E$ & $\mathrm{~L} / \mathrm{N}$ & $\mathrm{L}$ \\
\hline & Wallonia & $E$ & $\mathrm{~L} / \mathrm{N}$ & $\mathrm{L}$ \\
\hline \multirow[t]{2}{*}{ Germany } & Bavaria & $\mathrm{L} / \mathrm{N}$ & $\mathrm{L} / \mathrm{E}$ & $E$ \\
\hline & Meck.-VP & $\mathrm{L} / \mathrm{N}$ & $\mathrm{L} / \mathrm{E}$ & $\mathrm{L}$ \\
\hline
\end{tabular}

H1: Regions from dual systems are more likely to seek unmediated access than regions from cooperative systems.

$\mathrm{H}$ 2: The more influence a region has in domestic European policy-making, the less likely it is to seek unmediated access to European policy-making.

$\mathrm{E}=$ extensive unmediated access; $\mathrm{L}=$ limited unmediated access; $\mathrm{N}=$ no unmediated access.

Table 4: Intra-country Comparison of Pairs of Regions on Size, GDP/head and Level of Activity

\begin{tabular}{|l|l|l|l|l|}
\hline & & $\begin{array}{l}\text { More } \\
\text { Populated }\end{array}$ & $\begin{array}{l}\text { Economically } \\
\text { Stronger }\end{array}$ & More Active \\
\hline \multirow{2}{*}{ Germany } & Bavaria & 1 & 1 & 1 \\
\cline { 2 - 5 } & Meck.-VP & 0 & 0 & 0 \\
\hline \multirow{2}{*}{ Belgium } & Flanders & 1 & 1 & 1 \\
\cline { 2 - 5 } & Wallonia & 0 & 0 & 0 \\
\hline Austria & Carinthia & 1 & 0 & 1 \\
\cline { 2 - 5 } & Vorarlberg & 0 & 1 & 0 \\
\hline UK* & Scotland & 1 & 1 & 1 \\
\hline
\end{tabular}

$1=$ yes, $0=$ no

*Each region is compared to the other case study region from that member state. For Scotland, Northern Ireland is used as a comparator as it is the region most comparable to Scotland in terms of legislative powers. 